O.V. Bibik, L.I. Mazurenko, M.O. Shykhnenko

\title{
FORMATION OF CHARACTERISTICS OF OPERATING MODES OF SWITCHED RELUCTANCE MOTORS WITH PERIODIC LOAD
}

Purpose. The purpose of the article is to create dependencies of efficiency on effective power when changing the supply voltage and switching angles, pulsation speeds of the rotor from the moment of inertia of the drive and mechanical characteristics of switched-reluctance motors with a periodic load, developing recommendations to ensure their effective and reliable operating modes in single-cylinder piston compressors. Methodology. To carry out research simulation mathematic modeling was used, to calculate the nonlinear inductance dependence on current and rotor angle, the finite element method. Results. The measures of improve the efficiency and reliability of drives single-cylinder piston compressors on the basis of the SRM has been proposed. Originality. Approaches that provide maximum efficiency values and a regulated level of ripple speeds of rotors SRM of single-cylinder reciprocating compressors in the operating frequency control range, with periodic load have been developed. Practical value. Algorithm for changing the supply voltage and switching angles of the SRM of single-cylinder compressors, which provides maximum efficiency values SRM when the rotational speed changes within the 1:6 range, has been developed. The minimum values of the moments of inertia of the drive of single-cylinder compressors, providing a regulated level of pulsations of the rotational speed of the rotor SRM with its regulation, were determined. References 10, figures 5.

Key words: switched reluctance motor, periodic load, characteristics, efficiency, rotation frequency ripples.

Мета. Метою статті є формування залежностей ККД від корисної потужсності за зміни напруги жсияення і кутів комутаціï, пульсацій частоти обертання ротора від моменту інерції приводу та механічних характеристик вентильно-індукторних двигунів з періодичним навантаженням, розроблення рекомендацій щцдо забезпечення їх ефективних і надійних робочих режимів у складі одноциліндрових пориневих компресорів. Методика. Для проведення досліджень використано імітаційне математичне моделювання, для розрахунку нелінійної залежності індуктивності від струму і кута повороту ротора - метод скінченних елементів. Результати. Запропоновано заходи по підвищенню ефективності і надійності приводів одноциліндрових пориневих компресорів та основі ВІД. Наукова новизна. Розроблено підходи, що забезпечують максимальні значення ККД $і$ регламентований рівень пульсацій частоти обертання роторів ВІД одноциліндрових пориневих компресорів у робочому діапазоні регулювання частоти обертання з врахуванням періодичного навантаження. Практичне значення. Розроблено алгоритм зміни напруги жсивлення і кутів комутації ВІД одноциліндрових компресорів одинарної дї̈, щчо забезпечують максимальні значення ККД при регулюванні частоти обертання в межах діапазону 1:6. Визначено мінімальні значення моментів інерції приводу одноциліндрових компресорів з ВІД потужністю $100 \mathrm{Bm}$, щз забезпечують регламентований рівень пульсацій частоти обертання ротора ВІД при ї̈ регулюванні. Бібл. 10, рис. 5.

Ключові слова: вентильно-індукторний двигун, періодичне навантаження, характеристики, коефіціснт корисної дії, пульсації частоти обертання.

Цель. Целью статьи является формирование зависимостей КПД от полезной мощности при изменении напряжения питания и углов коммутации, пульсаций частоты вращения ротора от момента инерции привода и механических характеристик вентильно-индукторных двигателей с периодической нагрузкой, разработка рекомендаций по обеспечению их эффективных и надежных рабочих режсимов в составе одноцилиндровых поршневых компрессоров. Методика. Для проведения исследований использовано имитационное математическое моделирование, для расчета нелинейной зависимости индуктивности от тока и угла поворота ротора - метод конечных элементов. Результаты. Предложены меры по повыщению эффективности и надежнноти приводов одноцилиндровых пориневых компрессоров $и$ основе ВИД. Научная новизна. Разработаны подходы, которые обеспечивают максимальные значения КПД и регламентированный уровень пульсаций частоты вращения роторов ВИД одноцилиндровых пориневых компрессоров в рабочем диапазоне регулирования частоты вращения с учетом периодической нагрузки. Практическое значение. Разработан алгоритм изменения напряжения питания и углов коммутации ВИД одноцилиндровых компрессоров, который обеспечивает максимальные значения КПД при регулировании частоты вращения в пределах диапазона 1:6. Определены минимальные значения моментов инерции привода одноцилиндровых компрессоров с ВИД мощностью $100 \mathrm{Bm}$, обеспечивающие регламентированный уровень пульсаций частоты вращения ротора ВИД при ее регулировании. Библ. 10, рис. 5.

Ключевые слова: вентильно-индукторный двигатель, периодическая нагрузка, характеристики, коэффициент полезного действия, пульсации частоты вращения.

Problem definition. Features of operation of compressor plants require the use of a regulated electric drive, which provides energy-efficient operating modes [1-4]. Promising are induction motors with short-circuited rotors and frequency converters, which carry out a smooth adjustment of the rotational speed. Alternatives for them are controlled synchronous motors with electromagnetic excitation or with excitation from permanent magnets, as well as switched reluctance motors with reactive rotor [5].
The use of regulated switched reluctance motors due to their high energy performance, starting and adjusting properties provides solution of the problem of increasing the efficiency and reliability of electromechanical equipment operating under variable load conditions.

In order to create a competitive switched reluctance motors drive of hermetic piston compressors (HPCs), usually of single-cylinder compressors with power up to

(C) O.V. Bibik, L.I. Mazurenko, M.O. Shykhnenko 
$500 \mathrm{~W}$, with a significant reloading capacity (up to 3.0 ), it is necessary to provide efficient modes of their operation with the maximum values of efficiency in the range of 1:6 with the permissible level of the ripples of the rotor rotational speed and to reduce the weight and size indicators as well as costs of the main units of the machine.

Analysis of recent research and publications. The power indicators of electric drives with periodic loads are estimated using cyclic efficiency, which is determined in the period of one cycle of load variation. The long period of operation of the induction electric drive with periodic load with significant values of maximum and starting torques, in the mode of underloading leads to a decrease in energy efficiency and non-optimal energy use [6].

The level of the ripples of the rotation speed of motor rotors, traditionally induction, hermetically sealed piston compressors, is strictly regulated by standards and can not exceed $20 \%$. To reduce the amplitude of these ripples, on the motor rotor an additional inertial mass is mounted - the flywheel [7]. An important step to increase the reliability of the HPC drive is to reduce the ripples of rotational speed of the rotor to a predetermined level when it is adjusted in the required range. Analysis of the research of the switched reluctance drive [8] shows that in steady-state modes, its efficiency decreases by $4 \%$ with a double load reduction, which is confirmed by the results [9]. In this paper [9] the authors give the characteristics of the SRM with switch with C-reset and vibrational energy return for change in supply voltage and switching angles at a constant load. The switch and its control circuit are simple enough, which is important for the mass production of compressors, pumps, etc.

Studies in this direction need to be continued for the purpose of evaluating the efficiency and ripples of the rotational speed of the SRM rotor at the change in the angles of switching, voltage and moment of inertia of the drive, taking into account the periodic load. This will allow the development of measures for adjusting the SRM rotor speed of rotation in the composition of compressor equipment and to reduce the costs of motor development.

The goal of the work is to form the dependencies of the efficiency on the power output at the changes in the supply voltage and switching angles, the ripples of the rotor rotation speed on the moment of inertia of the drive and the mechanical characteristics of the switched reluctance motors with periodic load, the development of recommendations for the provision of their efficient and reliable operating modes in the single-cylinder piston compressors.

Mathematical model of the switched reluctance drive. The object of the study is a SRM, which is developed on the basis of an induction motor 4AA56A4Y3 (nominal power of $120 \mathrm{~W}$ and rotational speed of $3000 \mathrm{rpm}$ ) with a number of poles of $6 / 4$ and of phases $m=3$ phases with a switch with C-reset and a vibrational energy return [9]. A mathematical model [9] is used to study the modes of operation, the adequacy of which is confirmed by comparing the results of numerical and experimental studies. Its equations describe the structural elements of the motor and take into account their mutual influence.
For the phase of the switched reluctance machine, the following equation holds true

$$
\frac{d \psi_{p h}}{d t}=u_{p h}-i_{p h} \cdot R_{p h}
$$

where $u_{p h}, R_{p h}, i_{p h}, \psi_{p h}$ are the voltage at the output of the switch; resistance, current and flux linkage of the stator phase, respectively.

Phase current is determined as

$$
\frac{d i_{p h}}{d t}=\frac{1}{L_{p h}}\left(\frac{d \psi_{p h}}{d t}-i_{p h} \omega \frac{\partial L_{p h}}{\partial \theta_{p h}}\right)
$$

where $L_{p h}$ is the inductance of the stator phase, which is calculated by the finite element method [9] and is represented as a function of the current and the rotation angle of the rotor relative to the stator phase $L_{p h}=f\left(\theta_{p h}, i_{p h}\right)$; $\frac{\partial L_{p h}}{\partial \theta_{p h}}$ is the partial derivative of the tabular function $L_{p h}$ by the angle $\theta_{p h} ; \omega$ is the angular rotor rotation speed; $\theta_{p h}$ is the rotation angle relative to the stator phase. of the SRM

Electromagnetic moment formed by a single phase

$$
M_{p h}=\frac{1}{2} i_{p h}^{2} \frac{\partial L_{p h}}{\partial \theta_{p h}},
$$

and the total torque $\mathrm{M}$ of the switched reluctance motor from the action of $m$ phases

$$
M=\sum_{k=1}^{m} M_{p h(k)}
$$

Differential equations of motion

$$
\frac{d \omega}{d t}=\frac{1}{J}\left(M-M_{c}\right)
$$

where $J$ is the compressor moment of inertia; $M_{c}$ is the load torque.

The angle of rotation of the rotor is obtained from the equation

$$
\frac{d \theta}{d t}=\omega
$$

This angle relative to the stator phase

$$
\theta_{p h}=\bmod \left(\theta ; \frac{2 \pi}{Z_{R}}\right)
$$

where $Z_{R}$ is the number of rotor teeth

Mathematical modelling of the SRM is carried out in MATLAB - Simulink environment using the SymPowerSystems library. As the input parameters of the mathematical model, the angles $\theta_{o n}$ of switching on and $\theta_{\text {off }}$ of switching off, the voltage of the DC link $U_{d}$ and the phase inductance dependencies on the angle of rotation of the rotor and the phase current are used.

The mathematical model takes into account the dependence of the load torque of the single-cylinder HPC of single action on the rotation angle of the motor rotor $M_{c}=f(\theta)$ applied in the range $7 \pi / 9$ on the period $2 \pi$, the temporal dependence of which is shown in Fig. 1. To compare the calculations of operating modes with constant and periodic load, the average value $M_{c(\text { mean })}$ of 
the last one during the load period is used. For Fig. $1-$ $0.33 \mathrm{~N} \cdot \mathrm{m}$.

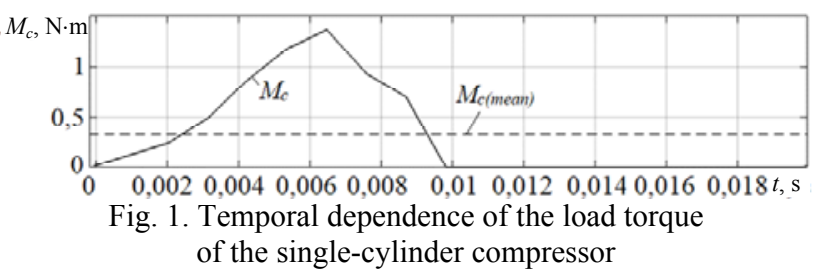

Numerical experiment. With the help of the mathematical model of the SRM, its efficiency is calculated taking into account losses in copper, magnetic and mechanical losses in operating modes at periodic loading. The calculation of the magnetic losses consisting of losses on hysteresis and eddy currents is based on the approach [10]. Mechanical losses are determined taking into account the change in rotor rotation speed and torque due to friction in bearings [9]. A method for controlling the SRM based on the change of the angle of switching on $\left(\theta_{\text {on }}=v a r\right)$ in the range $\theta_{\text {on }}=36^{\circ} \ldots .51^{\circ}$ at a constant clock angle $\left(\theta_{k}=30^{\circ}\right)$ and symmetric switching is used.

Dependencies of efficiency on the useful power $P_{2}$ at changes in the supply voltage and switching angles at steady and periodic load, when $M_{c(\text { mean })}=0.33 \mathrm{~N} \cdot \mathrm{m}$, are shown in Fig. 2. Each dependence is obtained at steady angles of switching on and switching off and change of voltage. The power of $103 \mathrm{~W}$ corresponds to the rotation speed of $3000 \mathrm{rpm}, 52 \mathrm{~W}-1500 \mathrm{rpm}$. The obtained dependencies of the efficiency with periodic loading with the moment of inertia $J=0.5 \cdot 10^{-3} \mathrm{~kg} \cdot \mathrm{m}^{2}$ practically do not differ from the efficiency of the motor with a constant load at $J=1 \cdot 10^{-4} \mathrm{~kg} \cdot \mathrm{m}^{2}$ (the constant torque equals the average value of the periodic load).

Shift of the switching zone towards the lowering of the angles of switching on and switching off leads to an increase in the motor efficiency, but the increase in efficiency is not observed throughout the entire range of loads. This allows to formulate an algorithm for changing the angles of commutation, which provides the maximum values of the efficiency of the switched reluctance motors of single-cylinder compressors on single action for the entire range of rotor rotation frequency control:

- in the range $3000 \ldots 1500 \mathrm{rpm}$ the SRMs should operate with commutation angles $\theta_{\text {on }}=36^{\circ}, \theta_{\text {off }}=66^{\circ}$ and the voltage $U_{d}=133 \ldots 77 \mathrm{~V}$;

- from 1500 to $1000 \mathrm{rpm}$ - with angles $\theta_{o n}=39^{\circ}$, $\theta_{\text {off }}=69^{\circ}, U_{d}=185 \ldots 137 \mathrm{~V}$;

- from 1000 to $500 \mathrm{rpm}$ - with $\theta_{\text {on }}=42^{\circ}, \theta_{\text {off }}=72^{\circ}$, $U_{d}=149 \ldots 88 \mathrm{~V}$.

The influence of the moment of inertia of the drive of a hermetic piston single-cylinder compressor on the ripples of the rotation speed of the SRM rotor for the range of regulation of the rotation speed of 1:6 at constant angles of commutation is investigated. It is shown that the regulated level of ripple $(\delta n=20 \%)$ with frequency regulation in the range of $1: 3(3000 \ldots 1000 \mathrm{rpm})$ can be provided at the moment of inertia of the drive $5 \cdot 10^{-4} \mathrm{~kg} \cdot \mathrm{m}^{2}$, in the range of $1: 4(3000 \ldots 750 \mathrm{rpm})-1 \cdot 10^{-3} \mathrm{~kg} \cdot \mathrm{m}^{2}$ (Fig. 3). Increasing the moment of inertia leads to a reduction of ripples and expansion of the range of regulation.
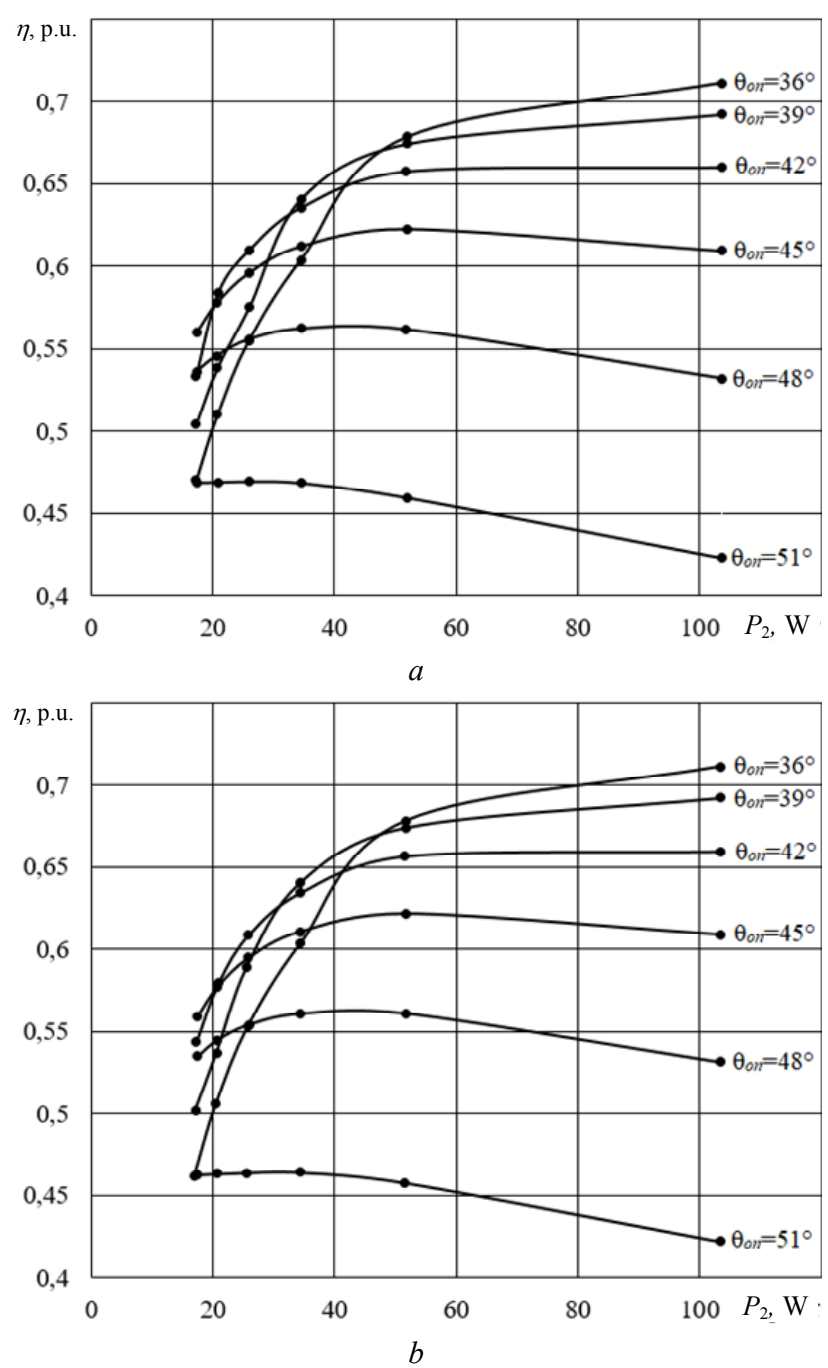

Fig. 2. Dependencies of efficiency on the useful power at changing the supply voltage for different switching angles at steady state $M_{c}=$ const $(a)$ and periodic $M_{c}=f(\theta)(b)$ load for moments of inertia $J=1 \cdot 10^{-4} \mathrm{~kg} \cdot \mathrm{m}^{2}$ and $J=1 \cdot 10^{-3} \mathrm{~kg} \cdot \mathrm{m}^{2}$, respectively

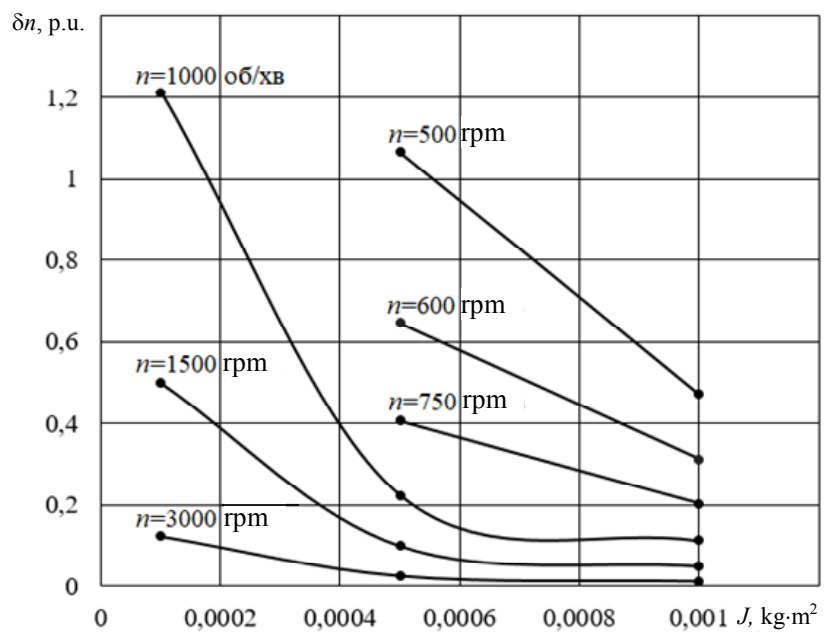

Fig. 3. Dependence of the ripples of the SRM rotor rotational speed on the moment of inertia of the drive of a single-cylinder HPC at steady angles $\theta_{\text {on }}=42^{\circ}, \theta_{\text {off }}=72^{\circ}$.

Extension of the range (up to 1:6) under this condition can be implemented: 
- for pulsating load of a two-cylinder compressor $\left(M_{c(\text { mean })}=0.33 \mathrm{~N} \cdot \mathrm{m}\right.$, moment of inertia of the drive $1 \cdot 10^{-3} \mathrm{~kg} \cdot \mathrm{m}^{2}$ ), which provides ripples of frequency in the range of $0.3 \ldots 12.8 \%$

- for less than twice the load at steady angles of switching due to a change in supply voltage.

Figure 4 shows the mechanical characteristics of the SRM at constant switching angles $\left(\theta_{\text {on }}=42^{\circ}, \theta_{\text {off }}=72^{\circ}\right)$ at changing the supply voltage in the range $31 \ldots 121 \mathrm{~V}$, which makes it possible to regulate the frequency of rotor rotation in the range of 1:6 with periodic load $M_{c(\text { mean })}=0.165 \mathrm{~N} \cdot \mathrm{m}$.

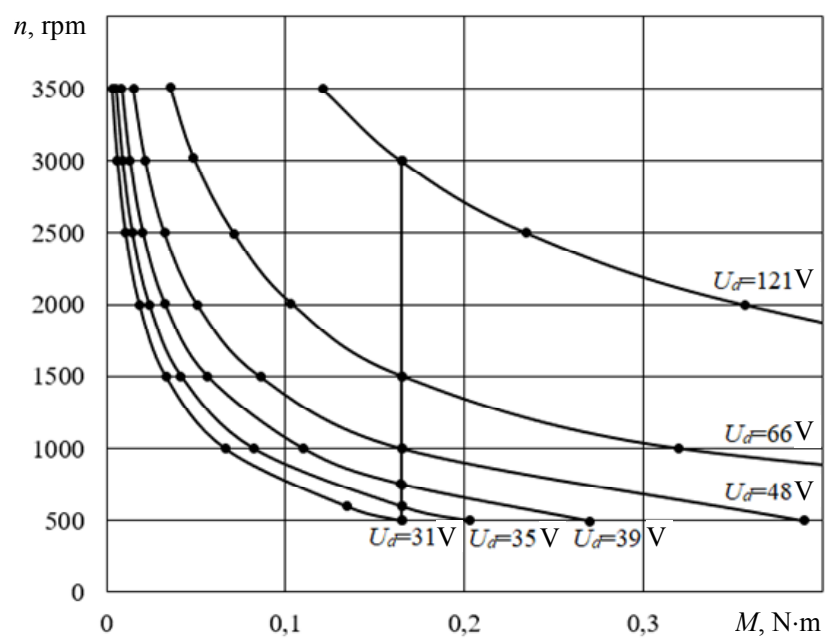

Fig. 4. Mechanical characteristics of the SRM at different values of supply voltage $\left(\theta_{\text {on }}=42^{\circ}, \theta_{\text {off }}=72^{\circ}\right)$.

The study of the effect of reducing the loading torque twice on the motor efficiency at changes in the angles of commutation (Fig. 5) is carried out. It is shown that when the rotation speed of the motor is reduced from 3000 to $500 \mathrm{rpm}$ for angles $\theta_{\text {on }}=36^{\circ}$ and $\theta_{\text {off }}=66^{\circ}$ and $M_{c(\text { mean })}=0.165 \mathrm{~N} \cdot \mathrm{m}$ its efficiency decreases by $1 \ldots 5 \%$ in comparison with $M_{c(\text { mean })}=0.33 \mathrm{~N} \cdot \mathrm{n}$.

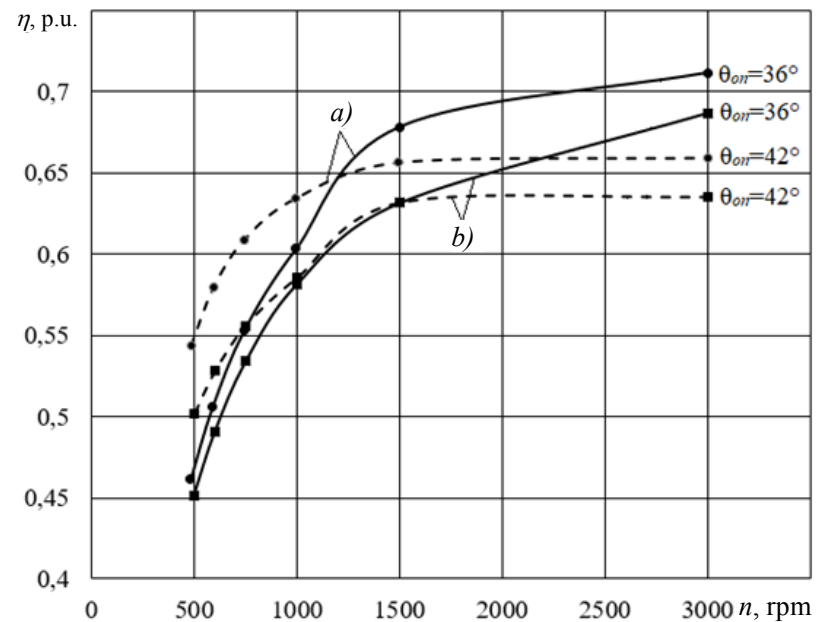

Fig. 5. Dependencies of efficiency on the rotational speed of the SRM rotor at regulating the rotor rotation speed by changing the supply voltage and constant angles:

a) $M_{c(\text { mean })}=0.33 \mathrm{~N} \cdot \mathrm{m} ; \quad$ b) $M_{c(\text { mean })}=0.165 \mathrm{~N} \cdot \mathrm{m}$
It is found that at the nominal rotational speed at $M_{c(\text { mean })}=0.165 \mathrm{~N} \cdot \mathrm{m}$, the highest efficiency is provided by switching angles $\theta_{\text {on }}=36^{\circ}, \theta_{\text {off }}=66^{\circ}$, at rotation frequencies in the range of $750 . .500 \mathrm{rpm}-$ by angles $\theta_{\text {on }}=42^{\circ}, \theta_{\text {off }}=72^{\circ}$, which allow to increase the efficiency by $2 \ldots .5 \%$ in comparison with the angles $\theta_{\text {on }}=36^{\circ}$ and $\theta_{\text {off }}=66^{\circ}$.

\section{Conclusions.}

1. Using the mathematical model, the operating modes of the switched reluctance motors with a switch and C-reset and a oscillatory return of energy of singlecylinder piston compressors at the changes in the supply voltage, switching angles and moment of inertia, taking into account the periodic load are investigated, which allowed to form the characteristics of the motors that provide an increase their energy efficiency and reliability.

2 . The algorithm for changing the supply voltage and switching angles of the SRM is proposed, which provides the maximum values of efficiency at change in the frequency of rotation in the range of 1:6.

3 . The values of moments of inertia of SRM of hermetic piston compressors are determined, which provide the recommended level of ripples of the rotational speed of the rotor of $20 \%$ in the ranges: 1:4 - for singlecylinder compressors, 1:6 - for double-cylinder ones.

4. The results of the research can be used for the creation of SRMs that operate in compressors and pumps in the areas of municipal and industrial use.

\section{REFERENCES}

1. Zhivitsa V.I., Onischenko O.A., Radimov I.N., Shevchenko V.B. Modern electric drive of refrigeration units. Refrigeration Engineering and Technology, 1999, iss.64, pp. 112-116. (Rus).

2. Andersen H.R. Motor drives for variable speed compressors: Introduction and state of the art analysis. PhD Thesis. Aalborg University Publ., 1996, vol.1, 62 p.

3. Jakobsen A., Rasmussen B. Energy optimization of domestic refrigerators Major energy saving by use of variable speed compressors and evaporator fans. International Appliance Manufacturing, 1998, pp. 105-109.

4. Monasry J.F., Hirayama T., Aoki T., Shida S., Hatayama M., Okada M. Development of large capacity and high efficiency rotary compressor. $24^{\text {th }}$ International Compressor Engineering Conference at Purdue, July 9-12, 2018, paper 2576.

5. Bibik O.V. Analysis and main trends of electromechanical energy converters for systems with periodic load. Works of the Institute of Electrodynamics of the National Academy of Sciences of Ukraine, 2016, no.43, pp. 37-43. (Ukr).

6. Bibik O.V. Rationale approaches to designing asynchronous motors with variable load. Bulletin of the National Technical University "KhPI». Series: Electrical Machines and Electromechanical Energy Conversion, 2019, no.4(1329), pp. 94-98. (Ukr). doi: 10.20998/2409-9295.2019.4.14.

7. Morozyuk L.I., Morozyuk T.V., Iastrebova L.V. Proektirovanie porshnevogo kompressora holodilnyih mashin $i$ teplovyih nasosov [Designing a piston compressor for refrigerating machines and heat pumps]. Odessa, OGAH Publ., 2003. 75 p. (Rus).

8. Andrada P., Blanque B., Perat J.I., Torrent M., Martinez E., Sanchez J.A. Comparative efficiency of switched reluctance and induction motor drives for slowly varying loads. International 
Conference on Renewable Energies and Power Quality (ICREPQ'06), 2007.

9. Mazurenko L.I., Bibik O.V., Bilyk O.A., Shihnenko M.O. Simulation mode and speed control of switched reluctance motor using a converter with the C-dump and the oscillation return of energy at changing switching angles. Bulletin of the National Technical University «KhPI». Series: Electrical Machines and Electromechanical Energy Conversion, 2016, no.11(1183), p. 64-69. (Ukr).

10. Kostenko M.P. Piotrovsky L.M. Elektricheskie mashinyi. V 2-h. ch. Ch.1. - Mashinyi postoyannogo toka. Transformatoryi. Uchebnik dlya studentov vyisshih tehnicheskih uchebnyih zavedeniy [Electric machines. In 2 parts. Part 1. - DC machines. Transformers. Textbook for students of higher technical educational institutions]. Leningrad, Energy Publ., 1972. 544 p. (Rus).

Received 11.06.2019

How to cite this article:

Bibik O.V., Mazurenko L.I., Shykhnenko M.O. Formation of characteristics of operating modes of switched reluctance motors with periodic load. Electrical engineering \& electromechanics, 2019, no.4, pp. 12-16. doi: 10.20998/2074272X.2019.4.02.
O.V. Bibik ${ }^{1}$, Candidate of Technical Science, Associate Professor,

L.I. Mazurenko ${ }^{1}$, Doctor of Technical Science, Professor, M.O. Shykhnenko ${ }^{1}$, Research Associate,

${ }^{1}$ The Institute of Electrodynamics of the NAS of Ukraine, 56, prospekt Peremogy, Kiev, 03057, Ukraine, phone +380443662491 ,

e-mail: bibik@ied.org.ua; mlins@ied.org.ua 